\title{
COMPARISON OF SELECTED METHODS USED FOR THE CALCULATION OF THE SNOWPACK SPATIAL DISTRIBUTION, BYSTŘICE RIVER BASIN, CZECHIA
}

\begin{abstract}
KUČEROVÁ, D., JENÍČEK, M. (2014): Comparison of selected methods used for the calculation of the snowpack spatial distribution, Bystřice River basin, Czechia. Geografie, 119, No. 3, pp. 199-217. - The knowledge of the water volume stored in the snowpack, including its spatial distribution, is vital for many hydrological applications. Such information is useful for hydrological forecasts and it is often used for the calibration of snowmelt runoff models. Data from four field measurements of the snow water equivalent (SWE) carried out in two winter seasons were assessed by ten interpolation methods. Measurements from both snow accumulation and snowmelt periods were evaluated. The ability of methods to predict SWE at unmeasured locations was assessed by the means of cross validation. The best prediction accuracy of SWE was achieved by means of multiple a simple linear regressions, residual kriging and cokriging methods. The accuracy was enhanced by the use of elevation, aspect, slope and vegetation as variables in the calculation of the SWE. Elevation and vegetation show a significant correlation with the SWE in the study area. The multiple regression gave best results for snow accumulation period. However, the spatial variability of SWE was not successfully explained for snowmelt periods.
\end{abstract}

KEY WORDS: snow - cross validation - interpolation methods.

The presented research was funded by the Czech Science Foundation, project No. P209/12/0997 "The impact of disturbance on the dynamics of fluvial processes in mountain landscapes" and project No. 13-32133S "Headwaters retention potential with respect to hydrological extremes" and by the Charles University in Prague, project No. 112110 "Modelling the runoff from snow cover to improve the flood prediction".

\section{Introduction}

Winter floods that occurred in central Europe on local and regional levels during years 1999 (Wetter et al. 2011), 2006 (Wachter 2007) and 2011 (Čekal et al. 2011) indicated the need for research on physical processes of the snowpack as well as on the development of tools which are applied for snowpack data acquisition, assessment and modelling. This is an important task for operational hydrology and flood forecasting systems as well as for the design of suitable flood protection measures. Increased risk of floods in central Europe exists namely in alpine and pre-alpine catchments which have the pluvio-nival flow regime. The accuracy of any simulated event depends on the selection of suitable methods describing the rainfall-runoff process and on the quality of data which form the input to the model (Konz, Seibert 2010; Váňová, Langhammer 2011). 
The knowledge of water volume accumulated in the snowpack in the basin is an important information for calibration and validation of snowmelt runoff models. Information about water volume stored in the snowpack is also used by water management companies in order to adjust the actual holding capacities of water reservoirs. In Czechia (the Czech Republic), such information is provided by Czech Hydrometeorological Institute (CHMI) which applies the linear dependence of the SWE on elevation (Čekal 2011). Most of the input data are available in the form of point values measured either in the field or using automatic sensors. It is therefore important to find a suitable method for SWE surface calculation using point data.

Usually, spatial variability of the snowpack is very high in mountainous conditions and this variability can be difficult described by point measurements at meteorological stations (Egli, Jonas, Meistner 2009). In general, the biggest differences are found between forests and open areas and among sites with different aspects and slopes (Jost et al. 2009; Čurda, Janský, Kocum 2011; Hribik et al. 2012; Jeníček et al. 2012). This conclusion applies primarily at local scales. Globally, the amount and distribution of the snowpack is most likely determined by the elevation (Essery 2003; Kutláková, Jeníček 2012).

The evaluation of the ability of selected geostatistical and deterministic methods to predict precipitation was carried out by Dirks et al. (1998); PardoIgúzquiza (1998); Carrera-Hernández, Gaskin (2007) and Haberlandt (2007). The works of Goovaerts (2000), Vicente-Serrano, Saz-Sánchez, Cudrat (2003) and Lloyd (2005) incorporate interpolation methods belonging to the global methods group. Most of the aforementioned studies concluded that geostatistical and global methods were the most suitable for the interpolation of precipitation because they include an independent variable (mainly the elevation) in the calculation of the dependent one.

However, the spatial distribution of the snow depth and of the snow water equivalent shows much higher variability than the liquid precipitation which is given by numerous factors influencing the snow accumulation and snowmelt (DeWalle, Rango 2008; Hribik et al. 2012; Jeníček et al. 2012). The inclusion of selected independent variables into snow water equivalent (SWE) calculation appears to be an effective way for SWE interpolation. Based on several results (Balk, Elder 2000; Erxleben, Elder, Davis 2002; López-Moreno, Nogués-Bravo 2006; Jost et al. 2007; López-Moreno, Stähli 2008), the elevation, vegetation (forest, clearing, open area) and, with minor importance, the aspect and slope belong to the most important factors influencing the SWE in the mountain catchments below the timberline. Therefore, the use of multiple regression is probably better and more effective for calculation of the SWE instead of the use of methods which don't include any independent variable (Molotch et al. 2005, Jost et al. 2007). The elevation seems to be one of the most important independent variables at the regional scale in the Czech conditions according to Bercha, Řičicová (2009) and Kutláková, Jeníček (2012).

The goal of this study is to assess ten interpolation methods in terms of their ability to predict the SWE at unmeasured locations. Measured data both from snow accumulation and snowmelt periods were used. We selected both geostatistical methods which apply only SWE data for interpolation and methods which additionally use one or more independent variables. We assumed that 


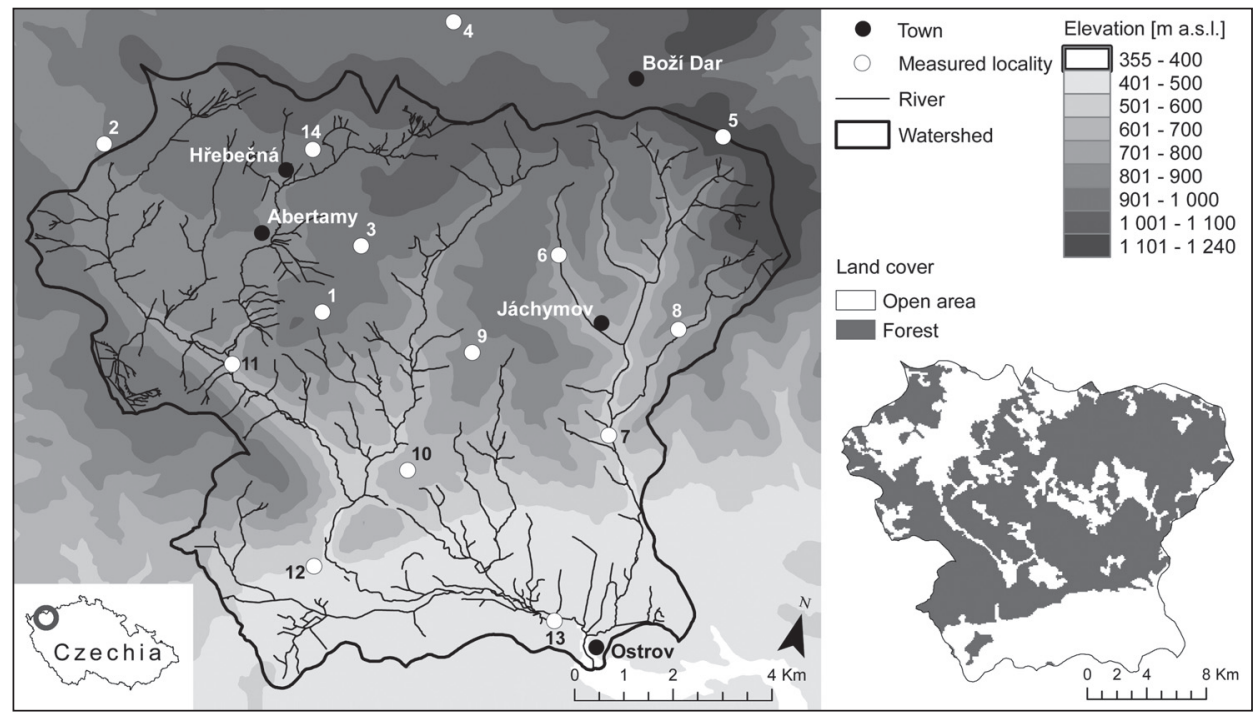

Fig. 1 - Map of the Bystřice River basin with location of snow water equivalent measurements.

including suitable independent variables into calculation could better describe and explain spatial variability of SWE. The study completes similar results carried out in different study areas and climatic conditions (Balk, Elder 2000; Erxleben, Elder, Davis 2002; López-Moreno, Nogués-Bravo 2006) but moreover it shows the differences in SWE interpolation during snow accumulation and snowmelt periods.

\section{Data and methods}

\subsection{Study area and data measurement}

The presented work was carried out in the Bystřice River basin $\left(127.6 \mathrm{~km}^{2}\right)$ situated in the NW of Czechia (Fig. 1). The study area includes the highest elevated basins in the Krušné Mountains (350-1,244 m a.s.l.) and there is nearly always a large amount of water stored in the snowpack over the winter, and thus a spring flood risk.

Measurements of snow water equivalent in the Bystřice River basin were carried out in 14 localities (Fig. 1) during two winter periods 2009/2010 and 2010/2011. Locations were chosen to provide a uniform coverage of the river basin and to ensure that the full range of elevations was represented. Locations including both open ground and forest were chosen when possible. In each location, the snow depth was measured 10 times along $100 \mathrm{~m}$ long transect in regular step; the SWE was measured 3 times along the same transect: at the beginning, in the middle and at the end. The mean snow depth and SWE values were calculated for each location and land cover type. The standard snow tube used for snowpack measurements in Czechia was applied. Additional 

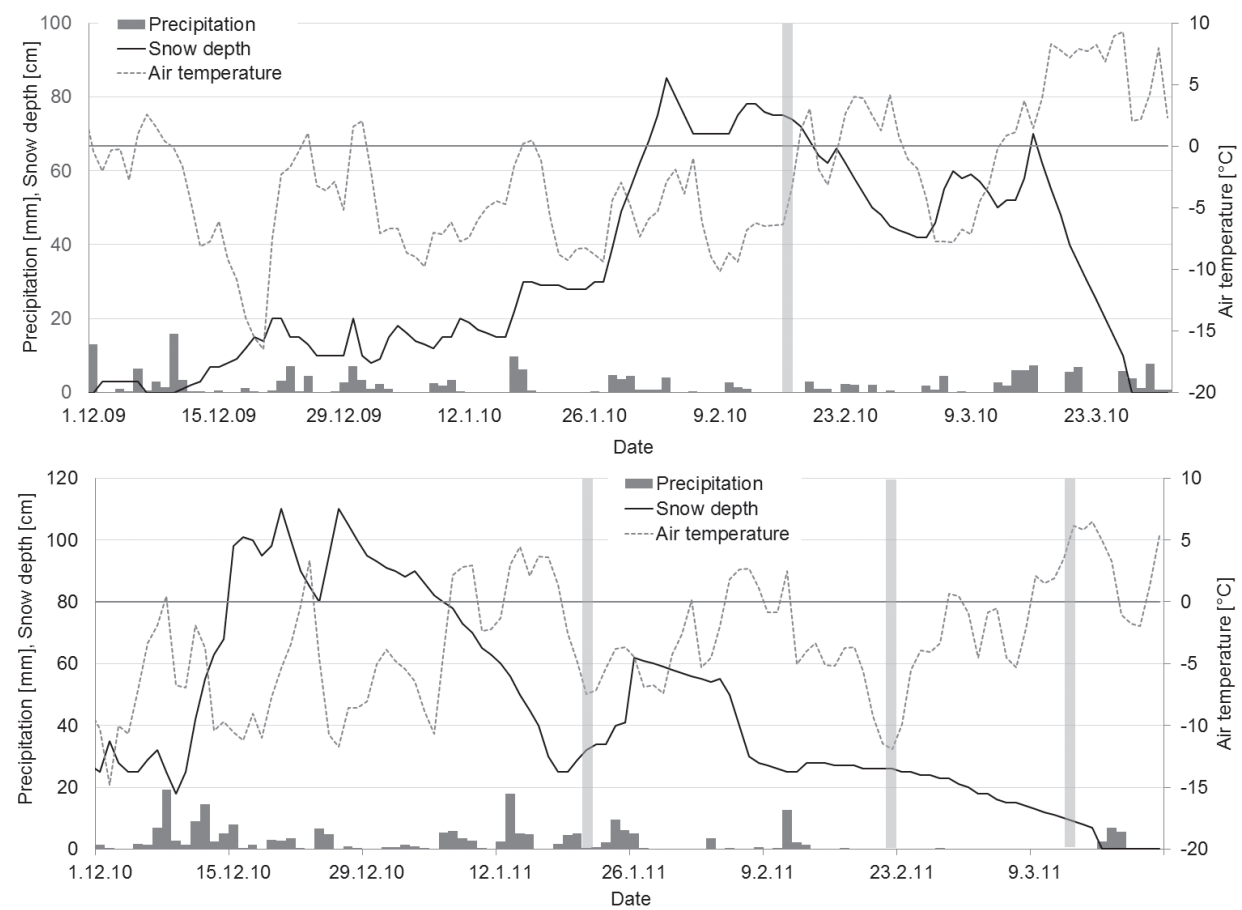

Fig. 2 - Precipitation, air temperature (gauging station Hřebečná) and snow depth (gauging station Abertamy) during winters 2009/10 and 2010/11. Grey columns indicate dates of measurement (data: CU in Prague and CHMI).

information consisting of snow depth recorded every 10 minutes (ultrasonic sensor) and meteorological data from our 2 gauged stations located within the basin were available for comparison with the measured data and for further analyses.

Four field surveys were processed within two winter periods 2009/2010 and 2010/2011. One field survey was carried out in the winter 2009/2010; three surveys were carried out during the winter season 2010/2011 (Table 1). All measurements represented different snow conditions during both accumulation period and snowmelt period (Fig. 2).

The dependence of the SWE on the elevation, forest, aspect (expressed as southing) and slope was proved by means of the Pearson coefficient of correlation (Table 2). Therefore, the interpolation methods using one or more mentioned factors as the independent variable could be applied for the calculation of the snow water equivalent as a dependent variable.

\subsection{Interpolation methods}

Ten interpolation methods (Table 3) were used in this study. The methods were applied in order to interpolate point values of the SWE onto grids with 
Table 1 - Characteristics of measured localities and snow water equivalent (in $\mathrm{mm}$ ) for four measuring dates

\begin{tabular}{|rcccrrrr|}
\hline No. & Slope $\left(^{\circ}\right)$ & Aspect & $\begin{array}{c}\text { Elevation } \\
\text { (m a.s.1.) }\end{array}$ & $\begin{array}{r}\text { Feb 17, } \\
2010\end{array}$ & $\begin{array}{c}\text { Jan 27, } \\
2011\end{array}$ & $\begin{array}{r}\text { Feb 22, } \\
2011\end{array}$ & $\begin{array}{c}\text { Mar 13, } \\
2011\end{array}$ \\
\hline 1 & 3.9 & N & 978 & 152 & - & 146 & 157 \\
2 & 2.1 & W & 900 & 149 & 243 & 196 & 166 \\
3 & 3.8 & S & 946 & 187 & 194 & 193 & 174 \\
4 & 5.5 & SW & 966 & 193 & 158 & 208 & 138 \\
5 & 2.5 & SW & 1,171 & 251 & 287 & 331 & 296 \\
6 & 21.6 & E & 784 & 148 & 165 & 183 & 129 \\
7 & 15.4 & NE & 520 & 92 & 38 & 3 & 0 \\
8 & 22.4 & SE & 766 & 143 & 66 & 79 & 0 \\
9 & 4.3 & NW & 830 & 125 & 43 & -3 & - \\
10 & 2.6 & S & 638 & 116 & 39 & 3 & 0 \\
11 & 12 & SW & 700 & 129 & 38 & 4 & 0 \\
12 & 6.9 & SE & 499 & 96 & 28 & 0 & 0 \\
13 & 0.9 & N & 405 & 84 & 23 & 0 & 0 \\
14 & 8.3 & SE & 964 & 145 & 177 & 164 & 47 \\
\hline
\end{tabular}

Table 2 - Pearson coefficient of correlation expressing the dependence of SWE on the elevation, forest, southing and slope. Significant correlations on 0.05 level are in italics.

\begin{tabular}{|lcccc|}
\hline Parameter & $\begin{array}{c}\text { Feb 17, 2010; } \\
\text { Accumulation }\end{array}$ & $\begin{array}{c}\text { Jan 27, 2011; } \\
\text { Accumulation } \\
\text { after rain-on-snow }\end{array}$ & $\begin{array}{c}\text { Feb 22, 2011; } \\
\text { Beginning of } \\
\text { the snowmelt }\end{array}$ & $\begin{array}{c}\text { Mar 13, 2011; } \\
\text { Snowmelt }\end{array}$ \\
\hline Elevation & 0.91 & 0.85 & 0.92 & 0.84 \\
Forest & -0.08 & 0.13 & 0.61 & 0.63 \\
Southing & 0.39 & 0.19 & 0.10 & 0.01 \\
Slope & -0.29 & -0.21 & -0.20 & -0.35 \\
\hline
\end{tabular}

Table 3 - The list of interpolation methods used in the study

\begin{tabular}{|llll|}
\hline \multicolumn{2}{|l}{ Interpolation method } & $\begin{array}{l}\text { Ability of data } \\
\text { extrapolation }\end{array}$ & $\begin{array}{l}\text { Independent } \\
\text { variable }\end{array}$ \\
\cline { 2 - 4 } $\begin{array}{l}\text { Deterministic } \\
\text { (local) }\end{array}$ & Thiessen polygons & No & None \\
& Inverse distance weighting (IDW) & No & None \\
& Global polynomial & Yes & None \\
& Local polynomial & Yes & None \\
& Radial basis function (RBF) & Yes & None \\
\hline \multirow{2}{*}{ Geostatistical } & Ordinary kriging (OK) & Yes & None \\
& Cokriging & Yes & Elevation \\
& Residual kriging (RK) & Yes & Elevation \\
\hline \multirow{2}{*}{ Global } & Linear regression & Yes & Elevation \\
& Multiple linear regression & Yes & Elevation, Forest, \\
& & & Southing, Slope \\
\hline
\end{tabular}

the resolution of $60 \times 60$ meters. Software STATISTICA (http://www.statsoft. com/), ArcGIS (http://www.esri.com/) and R (http://www.r-project.org/) were used for data analysis. 
The Thiessen polygons method (Thiessen 1911) is based on creating a polygon with borders located at the midpoint between neighbouring central points. The value of the central measured point is then assigned to the whole polygon (Shepard 1968).

The inverse distance weighting (IDW) consists of linear combination of data found in the defined surroundings of the unknown point with application of the weight that usually depends on the distance between input data and the unknown point (Tveito, Schöner 2002).

Polynomial interpolators describe the trend contained in the data using polynomials from the $1^{\text {st }}$ to the $\mathrm{n}^{\text {th }}$ degree. The choice of the polynomial affects the general surface structure (Tveito, Schöner 2002). Either global or local polynomials can be used. Global polynomial interpolators use one polynomial function interlaid through all input data; this procedure is generally more suitable for surfaces which demonstrate slow and gradual changes. However, dividing the area in partial segments is more suitable in case of local changes in the area of interest (Kraus 2007). The polynomials of the $1^{\text {st }}$ order were used in this study both for global and local polynomial functions.

Radial basis functions (RBF) incorporate several interpolators differing in the form of their equations. They stem from the same principle based on interlaying a plastic layer through input data which minimizes the surface curvature.

Geostatistical methods take into account spatial correlation between experimentally measured data which are displayed using a variogram (PardoIgúzquiza 1998). The experimental variogram provides a statistical description of spatial variability of two points as a function of the distance between them. The normal distribution of data is the basic assumption formulated for most types of kriging. The data were transformed by the use of a logarithmic transformation if the data were not normally distributed.

Co-kriging can be used when there is a significant relationship between the dependent and independent variables (in our case the elevation). The residual kriging is based on removing the global trend from input data. Consequently it is possible to interpolate local data variations using one of the kriging methods. The global trend which was removed at the beginning of the procedure is added back at the end (Martinez-Cob 1996).

The simple linear regression method describes the dependence of the predicted variable (SWE) on one explanatory independent variable by assuming and calculating a linear relationship (López-Moreno, Nogués-Bravo 2006). The elevation was used in our calculations as the independent variable.

The multiple regression enables to incorporate several independent parameters into SWE calculation which influence the snowpack distribution. Based on measurements and previous studies the elevation, forest presence, slope and aspect were used as independent variables. Both elevation and slope were expressed as real values (in $\mathrm{m}$ a.s.l. or decimal degrees, respectively) calculated from digital terrain model. Value 1 was used for forest and value 0 was used for open area. Aspect was expressed as southing which was calculated using Eq. 1. A similar equation is described in Jost et al. (2007).

$$
\text { Southing }=\left(\sin \left(\operatorname{aspect}_{\mathrm{rad}}-(\pi / 2)\right)+1\right) / 2
$$


The final model for calculating SWE distribution in different dates is (Eq. 2)

$$
S W E=a+b \times \text { elevation }+c \times \text { southing }+d \times \text { slope }+e \times \text { forest }
$$

with $a, b, c, d$ and $e$ as regression coefficients. All independent variables were expressed as normalized values using standard score. In case of non-normal distribution of data (according to Shapiro-Wilk test) a logarithmic transformation was used. A linear model was used for all data sets. The mutually independency of predictor variables was tested using Pearson correlation coefficient on 0.01 significance level.

\subsection{Cross validation}

The cross validation was used to evaluate the predictive ability of interpolation methods. The cross validation consists of consecutive removing of an individual input point and calculating the value at this removed point from the remaining data (Erxleben, Elder, Davis 2002). Both the original data set (with all input points) and the set obtained by cross validation were evaluated using various parameters: the coefficient of determination $\mathrm{R}^{2}$; mean-squared error MSE; mean error ME; root mean-squared error RMSE; mean absolute error MAE and Willmott's D (Willmott 1982).

The coefficient of determination provides a relative variability of the dependent variable explained successfully by the calculated dependence. The mean error should be equal to zero in the ideal model. The lower the MSE value is, the more accurate the interpolation method is and provides a better description of local variations in the data set. Furthermore, lower MAE and RMSE mean better characterization of global variations in the data set (Erxleben, Elder, Davis 2002). MAE and RMSE are generally considered to be the best model quality evaluation methods, and it is advisable to use both of them (Willmott 1982). Willmott's D (index of agreement) takes values from 0 to 1 . The value 1 means a perfect fit of the model (Willmott 1981). On the contrary, the value 0 indicates that the mean value calculated from the observed data provides an equally reliable prediction as the prediction itself.

The prediction of the SWE distribution provided by each selected interpolation method for several elevation ranges (Table 4) was compared to measured data.

\section{Results}

\subsection{Cross validation}

The best results of most methods were achieved on February 17, 2010 (Fig. 3). The preceding period before this date could be characterized by gradual accumulation of the snowpack in the Bystrice River basin from the beginning of December 2009. The evaluation of the predictive ability of the interpolation methods was slightly worse in the case of data sets measured in January 27, 2011 and February 22, 2011. There was a local maximum of the snowpack on the first mentioned date which occurred after a rain-on-snow event. The second 
Table 4 - Division of the Bystřice River basin in terms of elevation ranges and land covers

\begin{tabular}{|lcc|}
\hline Elevation range (m a.s.l.) & Area $\left(\mathrm{km}^{2}\right)$ & Area $(\%)$ \\
\hline $350-400$ & 0.28 & 0.2 \\
$401-500$ & 20.88 & 16.4 \\
$501-600$ & 9.72 & 7.6 \\
$601-700$ & 12.14 & 9.5 \\
$701-800$ & 13.75 & 10.8 \\
$801-900$ & 27.06 & 21.2 \\
$901-1,000$ & 31.71 & 24.9 \\
$1,001-1,100$ & 9.90 & 7.8 \\
$1,101-1,240$ & 2.11 & 1.7 \\
\hline Unforested area & 44.56 & 34.9 \\
Forested area & 83.00 & 65.1 \\
\hline
\end{tabular}

mentioned measurement occurred shortly after the beginning of the melting period characterized by slow decrease of the snowpack till the end of March. According to the cross validation, the worst results were achieved during the analysis of the data set of March 13, 2011 at the end of the melting period. This is not surprising as the SWE distribution is influenced by precipitation, air temperature, vegetation and topography. The increasing date of the year makes those factors more important and therefore, methods which included some independent variables into SWE calculation gave better results.

The Thiessen polygon method was evaluated as the least suitable interpolation method for SWE prediction by almost all parameters. The IDW was the second worst evaluated method (Fig. 3). However, the IDW method provided comparable or better results according to MSE, RMSE and MAE parameters for measured terms on January 27, 2011 and March, 132011 in comparison with methods which don't use the elevation as the secondary variable. Methods which don't use an independent variable for SWE prediction (RBF, global polynomial, local polynomial and ordinary kriging) achieved worse results than methods which use the elevation as the independent variable (cokriging, residual kriging, linear regression and multiple regression, Fig. 3). None of the methods was the best across all evaluated data sets, but results showed the best predictability of the multiple regression.

Figure 4 shows a comparison of measured and calculated SWE for all interpolation methods based on cross validation results. Calculated values were derived as a result of cross validation; it means that the value in the specific point was calculated based on all data except the measured value in the specific point. A better performance of global methods, especially linear and multiple regressions is clear from this figure both for accumulation periods (17 Feb 2010 and 21 Jan 2011) and melting periods (22 Feb 2011 and 13 March 2011).

\subsection{Spatial distribution of the calculated SWE}

The snow water equivalent was calculated for several elevation ranges by means of all interpolation methods (Fig. 5). Variability of methods representing 

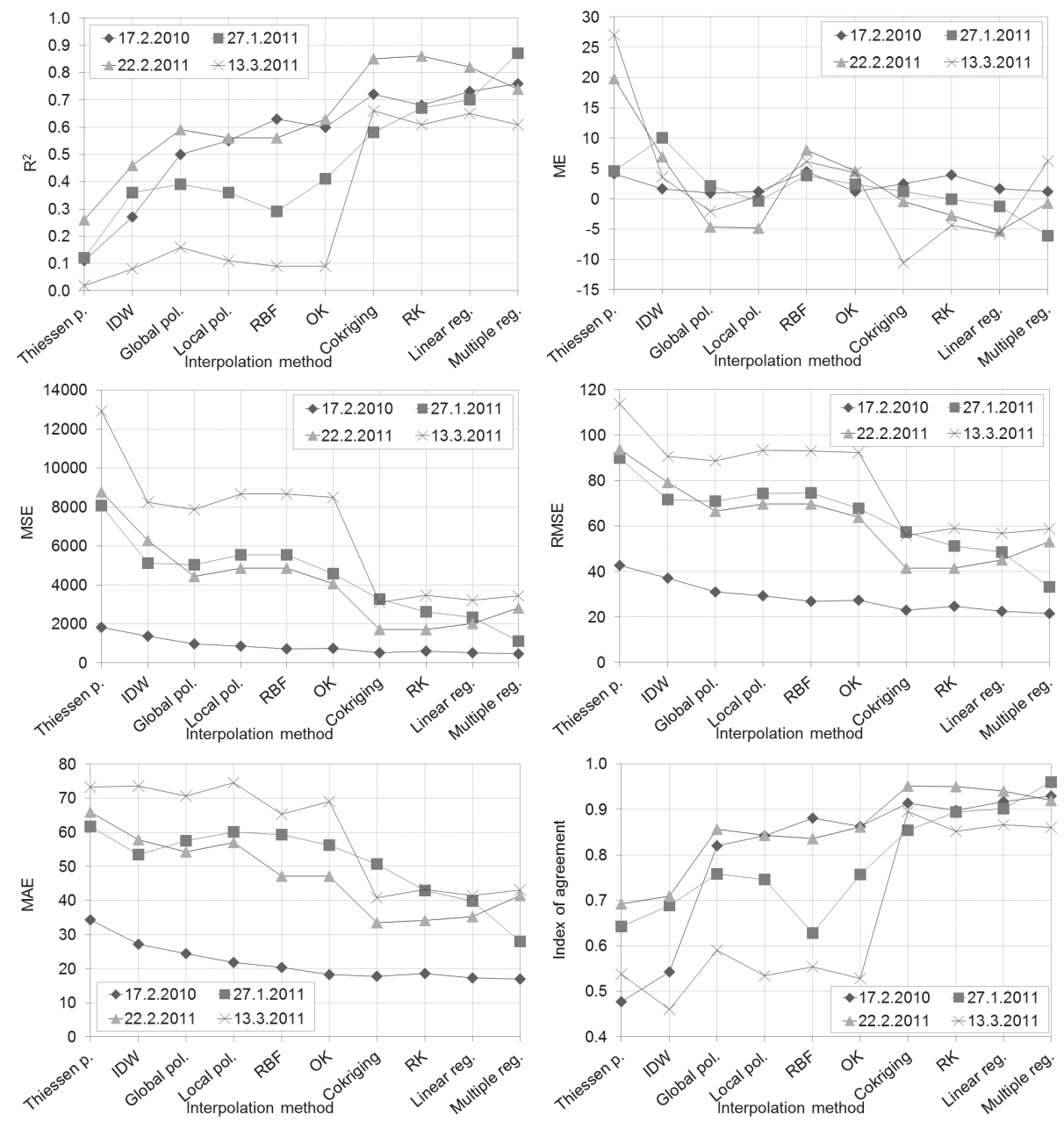

Fig. 3 - Evaluation of interpolation methods in terms of the predictive ability of the dependent variable (SWE) by means of the cross validation and using six evaluating parameters: $\mathrm{R}^{2}$ - coefficient of determination, $\mathrm{ME}$ - Mean error, MSE - Mean square error, RMSE - Root mean square error, MAE - Mean absolute error.

all dates of measurements is visible in all graphs in Figure 5. The variability of SWE averages in every elevation range calculated by all methods is higher in border elevation ranges, which is probably caused by different handling with data extrapolation. For example, linear regression causes a slight underestimation in comparison with measured data despite high correlation coefficients for elevation (Table 2).

The difference of the SWE distribution provided by selected methods strongly depends on the basin elevation and meteorological conditions preceding the date of the measurement (Fig. 2, 5 and 6). Based on the results, it is possible to conclude that closer to the end of winter, the differences between methods 




Fig. 4 - Comparison of measured SWE (x axis) and calculated SWE (y axis) for all interpolation methods based on cross validation results. Transparent circles represent accumulation periods (17 Feb 2010 and 21 Jan 2011); black circles represent melting periods (22 Feb 2011 and 13 March 2011). Dashed lines represent linear regression for accumulation period; solid lines represent linear regression for melting period.

become more significant. The highest differences were reached during the melting period in late February and in March 2011.

Meteorological conditions preceding the date of measurement are also important. The smallest differences are achieved after the period of continuous snow accumulation without partial thawing (before February 17, 2010). This result is not surprising and it was expected based on previous results from experimental catchments in the Krušné Mts. (Jeníček et al. 2012). The spatial variability of the snowpack in small catchments is much higher during the melt season in the spring because of the increasing importance of the topography 

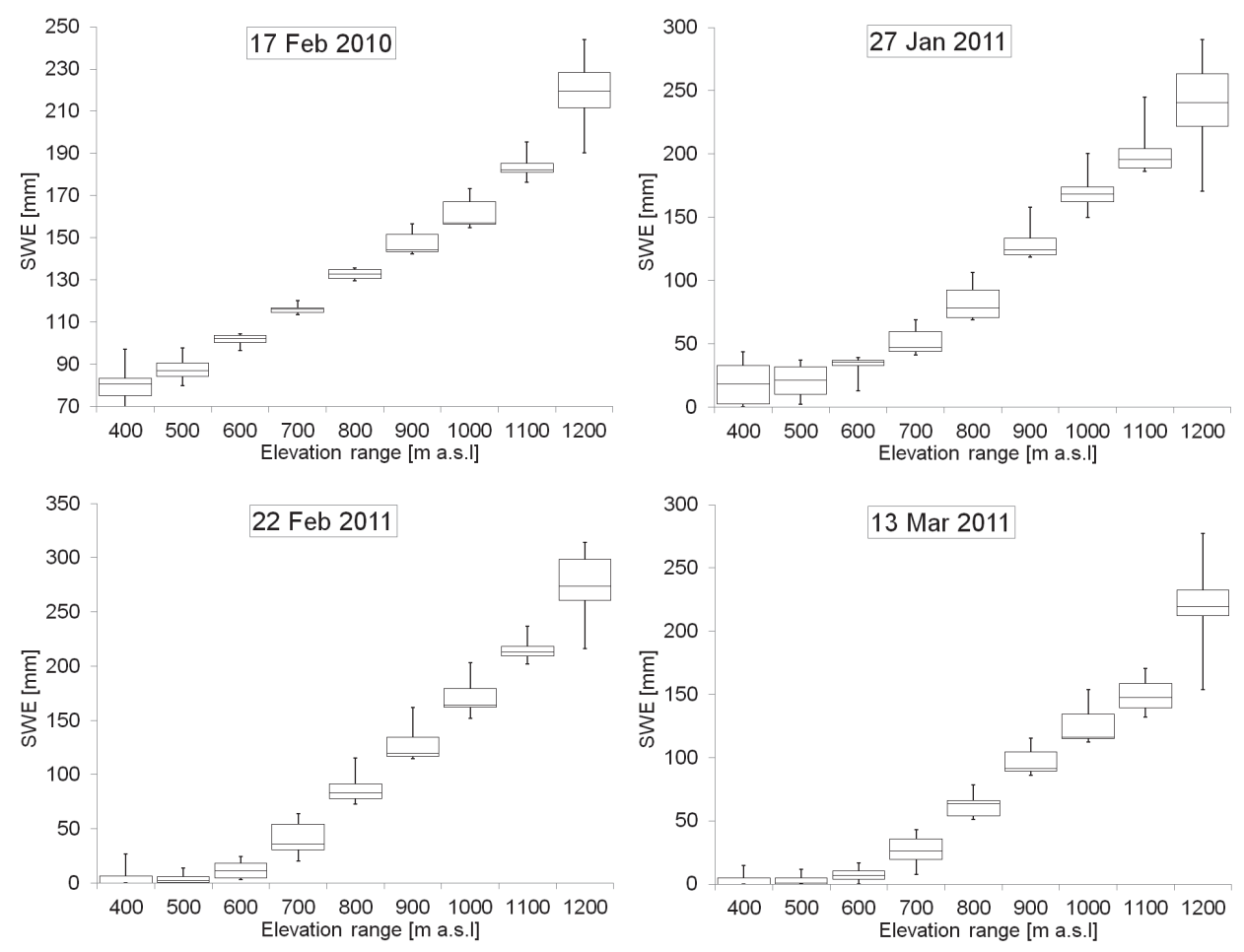

Fig. 5 - Calculated SWE in different elevation ranges in the Bystřice River basin. Each box plot represents the variability of the calculated SWE by means of all interpolation methods (maximum, minimum, quartiles). Please consider the different $\mathrm{y}$-axis ranges. The $\mathrm{x}$-axis descriptions indicate the upper border of the elevation ranges.

and solar radiation which intensify the role of aspects, slopes and vegetation. A worse performance was expected from interpolation methods which don't use topography, vegetation and climate factors for SWE calculations. This assumption was approved by the results.

Significant differences between methods were also registered on January 27, 2011 especially in case of methods which use the elevation for SWE calculation. The measurements were made after 10 days of snowpack accumulation. However, the rain-on-snow event, with strong SWE decrease at all elevations and local floods, occurred from January 8, 2011 to January 17, 2011. We assume that the mentioned snowmelt event reduced the influence of the topography (aspect, slope) and vegetation and highlighted the influence of the elevation (air temperature differences). Results shows better performance of methods using the elevation as the independent variable (cokriging, residual kriging, linear regression and multiple regression) and worse performance of the rest of the methods which aren't able to capture the SWE spatial differences. The conclusion can be supported both by the results of the cross validation (Figs. 3 and 4) and through a simple regression between model results and measured data (for correlation coefficients see Table 2). 
Table 5 - Percentage difference of the SWE in the Bystřice River basin calculated by selected interpolation methods compared to the mean of measured data

\begin{tabular}{|lccccccccccc|}
\hline Date & $\begin{array}{c}\text { Meas- } \\
\text { ured } \\
(\%)\end{array}$ & $\begin{array}{c}\text { Thies- } \\
\text { sen } \\
(\%)\end{array}$ & $\begin{array}{c}\text { IDW } \\
(\%)\end{array}$ & $\begin{array}{c}\text { Global } \\
\text { pol. }(\%)\end{array}$ & $\begin{array}{c}\text { Local } \\
\text { pol. }\end{array}$ & $\begin{array}{c}\text { RBF } \\
(\%)\end{array}$ & $\begin{array}{c}\text { OK } \\
(\%)\end{array}$ & $\begin{array}{c}\text { Cokri- } \\
\text { ging } \\
(\%)\end{array}$ & $\begin{array}{c}\text { RK } \\
(\%)\end{array}$ & $\begin{array}{c}\text { Linear } \\
\text { reg. } \\
(\%)\end{array}$ & $\begin{array}{c}\text { Mul- } \\
\text { tiple } \\
\text { reg. } \\
(\%)\end{array}$ \\
\hline $\begin{array}{l}\text { 17 Feb } \\
\begin{array}{l}\text { 2010 } \\
\text { 27 Jan }\end{array}\end{array}$ & 0.0 & -6.1 & -6.1 & -6.5 & -5.6 & -6.8 & -6.9 & -4.3 & -2.1 & -2.9 & -2.0 \\
$\begin{array}{l}2011 \\
\text { 22 Feb }\end{array}$ & 0.0 & -10.9 & -9.7 & -7.5 & -7.5 & -8.7 & -6.7 & -5.9 & 5.2 & 6.9 & 18.6 \\
$\begin{array}{l}2011 \\
\begin{array}{l}13 \mathrm{Mar} \\
2011\end{array}\end{array}$ & 0.0 & -12.7 & -10.9 & -7.2 & -6.8 & -10.2 & -7.3 & -5.3 & 5.7 & 9.5 & 18.4 \\
\hline
\end{tabular}

The prediction of the water volume stored in the snowpack in the Bystrice River basin is mostly underestimated in the case of deterministic and geostatistical methods and overestimated in the case of global methods (Table 5). The
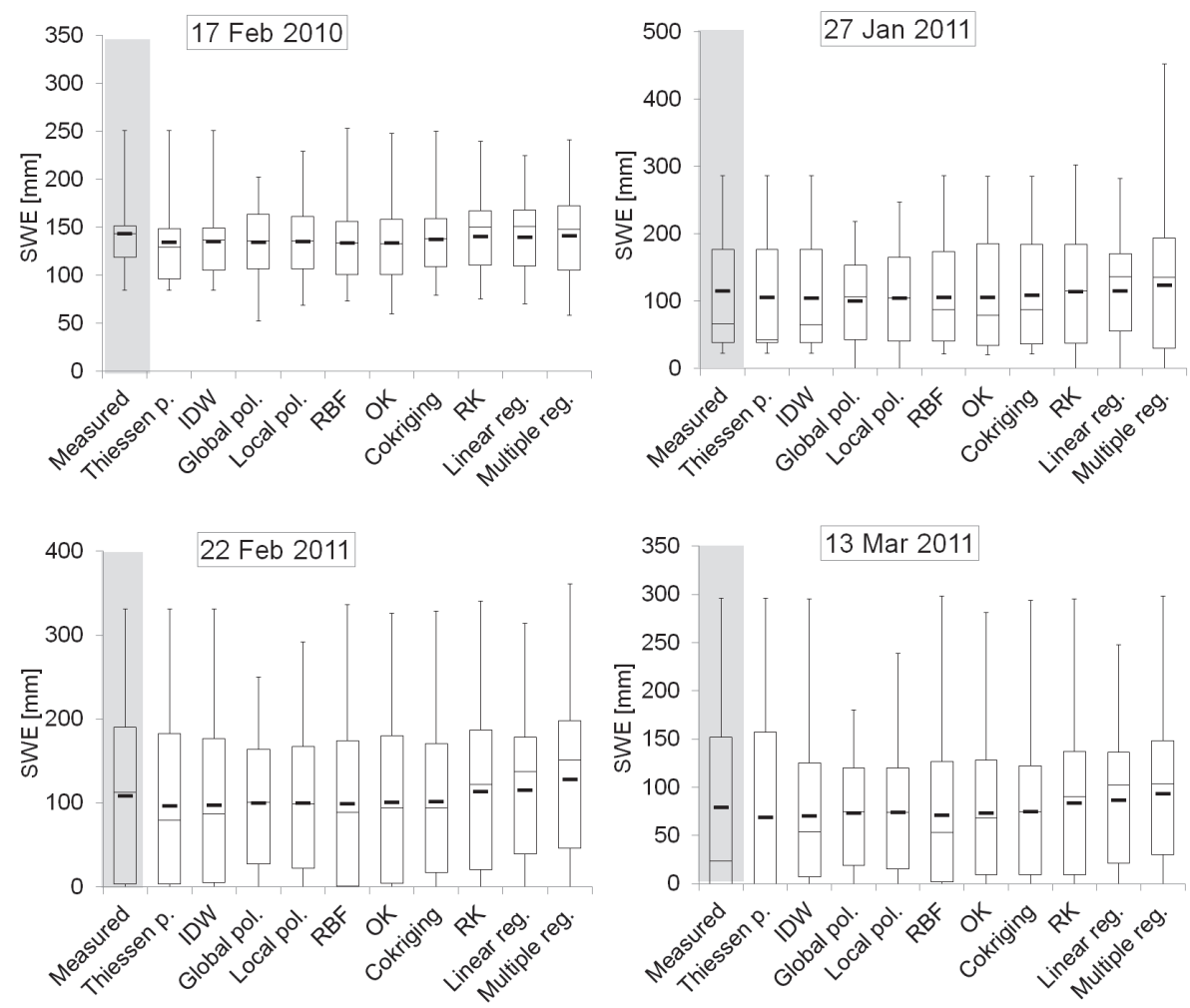

Fig. 6 - SWE variability in the Bystřice River basin calculated from the results and from observed data. Box plot represents SWE minimum, quartiles and maximum. Black marks inside boxplots represent the SWE average. First box plot represents the variability of the measured point data. 

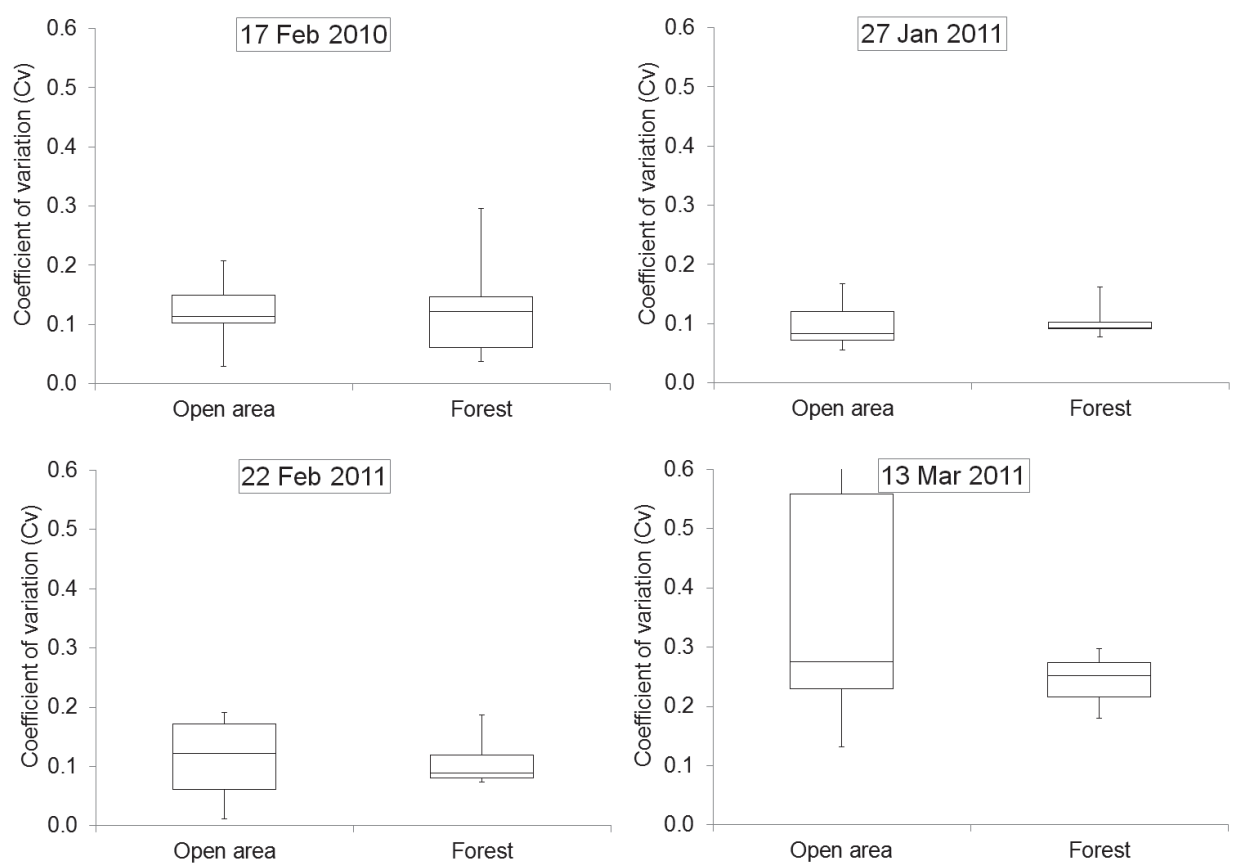

Fig. 7 - Coefficient of variations $(\mathrm{Cv})$ in the forest and in the open area representing the local variation of the SWE within one location for all measured dates.

SWE variability increases with the increasing date of the year, it means that the variability is higher during melting period (22 Feb 2011 and 13 Mar 2011) than during accumulation period (17 Jan 2010 and 27 Jan 2011).

The comparison of quartiles, maximum and minimum, shows underestimating of the maximum in the case of global and local polynomial methods in all dates (Fig. 6). The linear regression method shows an underestimation, the reason has been discussed above. But it should not be taken as a general rule; all differences are strongly influenced by the measured point location. It is also necessary to take into account only those methods which are able to extrapolate measured data in the assessment of extreme values.

The role of the forest and open area in the Bystrice River basin assessed by Jeníček et al. (2012) could be supported by the local variability of the SWE within specific measured localities (Fig. 7). Each box plot shows the variability of the coefficient of variation $(\mathrm{Cv})$ calculated from all SWE values measured in one locality (10 points) and in a specific land cover (forest, open area). From Figure 7 it seems that (1) local variations of SWE generally increase with the day of year (variations are lower in the accumulation period and higher during the snowmelt period), (2) local variations in the forest are higher during the accumulation period, while variations in open areas became more important during snowmelt period, (3) local SWE variations in the open areas during snowmelt period depend on the locality (there is a large variability of $\mathrm{Cv}$ ). Jost et al. (2007) mentioned higher local variability in the forest for the Cotton Creek 
study catchment in British Columbia. Based on our results it seems that during the accumulation period (17 Feb 2010 and 27 Jan 2011) there are higher local variations in the forest. However, during melting periods there is higher variability in open areas. We assume that this occurs due to the increasing amount of the solar radiation which causes higher importance of slopes and aspects. Once we obtain more measured data both from the study basin and from other basins in Czechia, we expect to prove or disprove the presented results.

\section{Discussion}

The presented results are burdened with numerous uncertainties which are connected both to data acquisition and to data analysis. All localities were chosen in order to provide a uniform coverage of the basin and in order to represent elevation zones. More measured points would probably lead to more reliable results, but due to logistical reasons it was not possible to make the measurement grid denser.

The digital terrain model (DTM) was used for residual kriging and linear regression methods. The calculated SWE depends on the DTM resolution (60 by 60 meters). A smaller resolution could lead to the incorrect calculation of the SWE in deep valleys which would not represent the reality.

According to the cross validation, the best predictive ability was provided by methods using at least the elevation for the prediction of the SWE (cokriging, residual kriging, linear regression and multiple regression). However, the assessment of the SWE in different elevation ranges or in different land covers shows that cokriging depends more on the exact location of measurement points compared to residual kriging and linear regressions. The possible reason is that the cokriging uses only the elevation from measured points while the residual kriging, linear regression and multiple regression use the DTM $(60 \times 60$ meter grid) for the SWE calculation.

The unsuitability of the Thiessen method is generally known and was proved both in this study and in the research of many authors (Dirks et al. 1998; Pardo-Igúzquiza 1998; Goovaerts 2000; Vicente-Serrano, Saz-Sánchez, Cudrat 2003; Haberlandt 2007). The IDW method didn't give usable results mainly due to the small number of measured points. However, Erxleben, Elder, Davis (2002) didn't improve the IDW method predictability even in a small area with a dense grid of measurement points. Better results would probably be reached in case of liquid precipitation interpolation instead of SWE interpolation (Dirks et al. 1998; Goovaerts 2000). The reason is that the variability of the snow depth and SWE is much higher than the variability of liquid precipitation due to snow redistribution by the wind, vegetation and topography influence. However, the IDW method didn't give satisfactory results in the mentioned study of Goovaerts (2000).

The SWE variability is affected by numerous independent variables. The influence of the elevation (air temperature change) and vegetation on the SWE distribution in the studied catchment seem to be the most important factors. The importance of aspects and slopes is minor in the study basin because of small slopes. These factors do not play a role in the context of the whole 
catchment but they are probably important when considering only the micro scale variability (variability within one locality). We don't have enough data to prove our assumption in the study basin but we are currently focussing on assessment of the role of different physical-geographical factors on the snowpack distribution on different spatial scales.

The effect of vegetation predominates locally in comparison with the regional effect of the elevation. The presence of forests and open areas in the river basin is important (Jost et al. 2007, Jeníček et al. 2012). Numerous studies show that slower snow melting in the forest is caused by lower short-wave radiation (Verbunt et al. 2003). The forest also affects wind speed, interception and density of the snowpack which are important factors during both accumulation and melting periods (López-Moreno, Stähli 2008; Holko et al. 2009; Stähli, Jonas, Gustafsson 2009; Hribik et al. 2102; Jeníček et al. 2012).

To increase the number of measured points is hardly possible due to time and financial demands. Therefore, the use of methods using one or more independent variables would be probably better and more effective (Molotch et al. 2005, Jost et al. 2007). The inclusion of an independent variable in the study (in our case the elevation, forest, southing and slope) appeared to be effective for SWE interpolation. These results could be supported by other studies (Haberlandt 2007; Jost et al. 2007; López-Moreno, Stähli 2008). Therefore, we would like to test more independent variables. Better results could be reached with more precise expression of forest cover (for example using Leaf Area Index, LAI), aspects or wind (computing of terrain curvature). The elevation, vegetation (forest cover, open area) and, with minor importance, the aspect and slope, are among the most important factors in the mountain catchments of Czechia.

\section{Conclusions}

The findings of the study are in agreement with the results achieved by other authors working in areas with similar climate and topography. According to most assessment parameters, the best predictive accuracy of the SWE in unmeasured points was achieved by means of global and geostatistical interpolation methods which take into account one or more parameters (elevation, forest cover, aspect, slope) as the independent variable (multiple regression, linear regression, residual kriging and cokriging) compared to the rest of methods (Thiessen polygons, inverse distance weighting, global and local polynomial, radial basis functions and ordinary kriging).

The predictive ability may be enhanced by testing the influence of more independent variables in the calculation of the dependent one; mainly parameters connected with vegetation and topography. The better expression of vegetation (for example using LAI) for SWE calculation could bring an improvement in our small study catchments. The use of multiple regression method seems to be advisable based on results.

A suitable set of independent variables is crucial for the calculation of the snowpack distribution. However, the set may differ from basin to basin depending on local climate and topography. Our results show that the set of variables 
may differ also within one winter period thanks to the increasing role of vegetation and aspect during snowmelt.

We also thank to Prof. Richard D. Crago from Bucknell University (Pennsylvania, USA) for English correction.

\section{References:}

BALK, B., ELDER, K. (2000): Combining binary decision tree and geostatistical methods to estimate snow distribution in a mountain watershed. Water Resources Research, 36, pp. 1326.

BERCHA, Š., ŘIČICOVÁ, P. (2009): Vyhodnocení sněhových zásob v ČHMÚ. In: Hanková R., Klose Z., Pavlásek J. (eds.): XIV. Medzinárodné stretnutie snehárov. ČZU Praha, Praha, pp. 6168.

BRAZDIL, R., KIRCHNER, K., eds. (2007): Vybrané přírodní extrémy a jejich dopady na Moravě a ve Slezsku. Masarykova Univerzita, Český hydrometeorologický ústav, Ústav geoniky AV ČR, Brno, Praha, Ostrava, $432 \mathrm{pp}$.

CARRERA-HERNÁNDEZ, J.J., GASKIN, S.J. (2007): Spatio temporal analysis of daily precipitation and temperature in the Basin of Mexico. Journal of Hydrology, 336, pp. 231-249.

ČEKAL, R. (2011): Výpočet zásoby vody ve sněhové pokrývce v GIS. Metodický pokyn MP $\mathrm{NH}-4 / 2011$, Ceský hydrometeorologický ústav, Praha, 12 pp.

ČEKAL, R., RYGLEWICZ, M., FRYČ, T., BOŘÍKOVÁ, L., SUCHÁ, M., PŘIBYL, J., KOTEK, R. (2011): Zpráva o povodni v lednu 2011. Český hydrometeorologický ústav, Praha, 73 pp.

ČURDA, J., JANSKÝ, B., KOCUM, J. (2011): Vliv fyzickogeografických faktorů na extremitu povodní v povodí Vydry. Geografie, 116, No. 3, pp. 335-353.

DEWALLE, D., RANGO, A. (2008): Principles of snow hydrology. Cambridge University Press, Cambridge, $410 \mathrm{pp}$.

DIRKS, K.N., HAY, J.E., STOW, C.D., HARRIS, D. (1998): High-resolution studies of rainfall on Norfolk Island. Part II: Interpolation of rainfall data. Journal of Hydrology, 208, pp. 187-193.

EGLI, L., JONAS, T., MEISTNER, R. (2009): Comparison of different automatic methods for estimating snow water equivalent. Cold Regions Science and Technology, 57, pp. 107-115.

ERXLEBEN, J., ELDER, K., DAVIS, R. (2002): Comparison of spatial interpolation methods for estimating snow distribution in the Colorado Rocky Mountains. Hydrological Processes, 16, pp. 3627-3649.

ESSERY, R. (2003): Aggregated and distributed modelling of snow cover for a high-latitude basin. Global and Planetary Change, 38, pp. 115-120.

GOOVAERTS, P. (2000): Geostatistical approaches for incorporating elevation in to the spatial interpolation of rainfall. Journal of Hydrology, 228, pp. 113-129.

HABERLANDT, V. (2007): Geostatistical interpolation of hourly precipitation from rain gauges and radar for a large-scale extreme rainfall event. Journal of Hydrology, 332, pp. 144-157.

HOLKO, L., ŠKVARENINA, J., KOSTKA, Z., FRIČ, M., STAROŇ, J. (2009): Impact of spruce forest on rainfall interception and seasonal snow cover evolution in the Western Tatra Mountains, Slovakia. Biologia, 64, No. 3, pp. 594-599.

HRIBIK, M., VIDA, T., SKVARENINA, J., SKVARENINOVA, J., IVAN, L. (2012): Hydrological effects of norway spruce and european beech on snow cover in a mid-mountain region of the Polana Mts., Slovakia. Journal of Hydrology and Hydromechanics, 60, No. 4, pp. 319-332.

JENÍČEK, M., BEITLEROVÁ, H., HASA, M., KUČEROVÁ, D., PEVNÁ, H., PODZIMEK, S. (2012): Modelling snow accumulation and snowmelt runoff - present approaches and results. AUC Geographica, 47, No. 2, pp. 15-24.

JOST, G., WEILER, M., GLUNS, D.R., ALILA, Y. (2007): The influence of forest and topography on snow accumulation and melt at the watershed-scale. Journal of Hydrology, 347, No. 1-2, pp. 101-115. 
JOST, G., MOORE, R.D., WEILER, M., GLUNS, D.R., ALILA, Y. (2009): Use of distributed snow measurements to test and improve a snowmelt model for predicting the effect of forest clear-cutting. Journal of Hydrology, 376, No. 1-2, pp. 94-106.

KONZ, M., SEIBERT, J. (2010): On the value of glacier mass balances for hydrological model calibration. Journal of Hydrology, 385, pp. 238-246.

KRAUS, J. (2007): Geostatistika jako prostorové modelování statistických jevů. Statistika, 6 , pp. 490502.

KUTLÁKOVÁ, L., JENÍČEK, M. (2012): Modelling snow accumulation and snowmelt in the Bystřice River Basin. Geografie, 117, No. 1, pp. 110-125.

LLOYD, C.D. (2005): Assessing the effect of integrating elevation data into the estimation of monthly precipitation in Great Britain. Journal of Hydrology, 308, pp. 128-150.

LÓPEZ-MORENO, J.I., NOGUÉS-BRAVO, D. (2006): Interpolating local snow depth data: an elevation of methods. Hydrological Processes, 20, pp. 2217-2232.

LÓPEZ-MORENO, J.I., STÄHLI, M. (2008): Statistical analysis of the snow cover variability in a subalpine watershed: Assessing the role of topography and forest interactions. Journal of Hydrology, 348, pp. 379-394.

MARTINEZ-COB, A. (1996): Multivariate geostatistical analysis of evapotranspiration and precipitation in mountains terrain. Journal of Hydrology, 174, pp. 19-35.

MOLOTCH, N.P., COLEE, M.T., BALES, R.C., DOZIER, J. (2005): Estimating the spatial distribution of snow water equivalent in an alpine basin using binary regression tree models: the impact of digital elevation data and independent variable selection. Hydrological Processes, 19, pp. 1459-1479.

PARDO-IGÚZQUIZA, E. (1998): Comparison of geostatistical methods for estimating the areal average climatological rainfall mean using data on precipitation and topography. International Journal of Climatology, 18, pp. 1031-1047.

SHEPARD, D. (1968): A two-dimensional interpolation function for irregularly-spaced data. In: Blue, R.B., Rosenberg, A.M. (eds.): Proceedings of the $196823^{\text {rd }}$ ACM national conference. ACM Press, New York, pp. 517-524.

STÄHLI, M., JONAS, T., GUSTAFSSON, D. (2009): The role of snow interception in wintertime radiation processes of a coniferous sub-alpine forest. Hydrological processes, 23, pp. 2498-2512.

THIESSEN, A.H. (1911): Precipitation averages for large areas. Monthly Weather Review, 39, pp. 1082-1084.

TVEITO, O.E., SCHÖNER, W. (2002): Applications of spatial interpolation of climatological and meteorological elements by the use of geographical information system (GIS). Cost 719 Report No 1. Rapport Klima, 28, 2002.

VÁŇOVÁ, V., LANGHAMMER, J. (2011): Modeling the impact of land cover changes in flood mitigation in the upper Lužnice basin. Journal of Hydrology and Hydromechanics, 59, No. 4, pp. 262-274.

VERBUNT, M., GURTZ, J., JASPER, K., LANG, H., WARMERDAM, P., ZAPPA, M. (2003): The hydrological role of snow and glaciers in alpine river basins and their distributed modeling. Journal of Hydrology, 282, pp. 36-55.

VICENTE-SERRANO, S.M., SAZ-SÁNCHEZ, M.A., CUDRAT, J.M. (2003): Comparative analysis of interpolation methods in the middle Ebro Valley (Spain): application to annual precipitation and temperature. Climate Research, 24, pp. 161-180.

WACHTER, K. (2007): The Analysis of the Danube Floods 2006. ICPDR - International Commission for the Protection of the Danube River, Vienna, $54 \mathrm{pp}$.

WETTER, O., PFISTER, C., WEINGARTNER, R., LUTERBACHER, J., REIST, T., TRÖSCH, J. (2011): The largest floods in the High Rhine basin since 1268 assessed from documentary and instrumental evidence. Hydrological Sciences Journal, 56, pp. 733-758.

WILLMOTT, C.J. (1981): On the validation of models. Physical Geography, 2, pp. 184-194.

WILLMOTT, C.J. (1982): Some comments on the evaluation of model performance. Bulletin of the American Meteorological Society, 63, No. 11, pp. 1309-1313. 


\section{SROVNÁNÍ VYBRANÝCH METOD POUŽITÝCH PRO VÝPOČET PROSTOROVÉ DISTRIBUCE SNĚHU, POVODÍ BYSTŘICE, ČESKO}

Znalost objemu vody akumulované ve sněhové pokrývce a její prostorové rozložení je důležité pro mnoho hydrologických aplikací. Tato informace je užitečná pro hydrologické předpovědi a je také často používána pro kalibraci modelů simulující tání sněhu a odtok ze sněhové pokrývky.

Cílem výzkumu bylo zhodnocení deseti interpolačních metod z hlediska jejich schopnosti výpočtu vodní hodnoty sněhu (SWE, snow water equivalent) v neznámých bodech. K hodnocení byla použita data SWE měřená na čtrnácti lokalitách v povodí Bystřice v Krušných horách (127,6 km²) v zimních sezónách 2009/10 a 2010/11 jak v období akumulace sněhu, tak v období tání sněhu. Vodní hodnota sněhu byla měřena v různých typech lesního porostu a na otevřené ploše. Uvedená studie doplňuje výsledky studií provedené v jiných územích, navíc ale přináší oddělené hodnocení předpovědní schopnosti metod v době akumulace a v době tání sněhu.

Data byla hodnocena pomocí deseti interpolačních metod. Byly aplikovány jednak geostatistické metody, které $\mathrm{k}$ výpočtu používají pouze měřených hodnot SWE, a také metody, které $\mathrm{k}$ výpočtu využívají navíc jednu nebo více nezávislých proměnných. Výchozím předpokladem bylo, že zahrnutí vhodné nezávislé proměnné umožní vysvětlit větší část celkové variability závislé proměnné (SWE). Jednotlivé metody byly hodnoceny pomocí kř́žové validace a šesti hodnotících kritérií - koeficient determinace, průměrná chyba, průměrná kvadratická chyba, standardní chyba odhadu (RMSE), průměrná absolutní chyba a index shody (Willmott's D).

Výsledky ukázaly na vhodnost použití globálních a geostatistických metod, které pro výpočet SWE používají jeden nebo více nezávislých parametrů, například nadmořskou výšku, orientaci svahů, sklon a typ vegetace. Díky tomu byly nejlépe hodnoceny metody jednoduché a vícenásobné lineární regrese, residual kriging a cokriging. Výsledky ostatních metod již nebyly přiliš uspokojivé (Thiessenovy polygony, inverse distance weighting, globální a lokální polynomy, radial basis functions a ordinary kriging). Výsledky byly zpřesněny po zahrnutí více nezávislých parametrů do výpočtu závislé proměnné, především zahrnutí parametrů vztahujících se $\mathrm{k}$ topografii a vegetaci. Díky tomu byla během období akumulace sněhu nejlépe hodnocená metoda vícenásobné lineární regrese. Naproti tomu nebyla uspokojivě vysvětlena prostorová variabilita sněhu během období tání. Zlepšení by mohlo přinést přesnější popis vegetace, například pomocí analýzy hemisférických snímků oblohy a vegetace.

Studie ukázala, že pro výpočet prostorového rozložení sněhu je důležité identifikovat vhodnou skupinu nezávislých parametrů. Tato množina parametrů ale může být pro každé povodí rozdílná a může se také měnit v čase. Výsledky ukázaly, že se tato množina může měnit i v závislosti na konkrétních meteorologických podmínkách během zimy, především v době akumulace a v době tání sněhu.

Obr. 1 - Poloha povodí Bystřice s vyznačenými místy měření vodní hodnoty sněhu. V legendě: nadmořská výška, město, měřené lokality, vodní tok, hranice povodí. Krajinný pokryv: otevřená plocha, les.

Obr. 2 -Úhrn srážek (sloupce), teplota vzduchu na stanici Hřebečná (přerušovaná čára) a výška sněhu na stanici Abertamy (plná čára) během zim 2009/10 a 2010/11. Šedé sloupce označují den měření. Data: Přírodovědecká fakulta Univerzity Karlovy v Praze a ČHMÚ.

Obr. 3 -Hodnocení interpolačních metod na základě jejich schopnosti odhadu závislé veličiny (SWE) pomocí křížové validace a šesti parametrů: $\mathrm{R}^{2}$ - koeficient determinace, $\mathrm{ME}$ průměrná chyba, MSE - průměrná kvadratická chyba, RMSE - standardní chyba odhadu, MAE - průměrná absolutní chyba.

Obr. 4 -Srovnání měřené SWE (osa x) a vypočtené SWE (osa y) pro všechny interpolační metody na základě křrižové validace. Průhledné značky představují hodnoty během akumulace sněhu (17. 2. 2010 a 21. 1. 2011), černé značky představují hodnoty během tání sněhu (22. 2. 2011 a 13. 3. 2011). Přerušovaná čára představuje lineární regresní 
model pro období akumulace sněhu, plná čára představuje lineární regresní model pro období tání sněhu.

Obr. 5 -Vypočtená SWE v různých nadmořských výškách povodí Bystřice. Každý box-plot reprezentuje variabilitu vypočtené SWE pomocí všech interpolačních metod (maximum, minimum, kvartily). Pozor na různý rozsah osy y. Hodnoty na ose $\mathrm{x}$ reprezentují horní hranici daného výškového rozpětí.

Obr. 6 -Variabilita SWE v povodí Bystřice vypočtená na základě vypočtené a pozorované SWE. Box-ploty reprezentují minimum, kvartily a maximum hodnot. Černé značky uvnitř box-plotů reprezentují aritmetický průměr hodnot. První box-plot zobrazuje variabilitu měřených dat.

Obr. 7 -Koeficient variace $(\mathrm{Cv})$ v lese a na otevřené ploše, který reprezentuje lokální rozdíly SWE uvnitř jedné lokality během všech termínů měření.

Authors' affiliation: D. Kučerová: Charles University in Prague, Faculty of Science, Department of Physical Geography and Geoecology, Albertov 6, 12843 Praha 2, Czechia. M. Jeníček: University of Zurich, Department of Geography, Winterthurerstrasse 190, CH-8057 Zurich, Switzerland; Charles University in Prague, Faculty of Science, Department of Physical Geography and Geoecology, Albertov 6, 12843 Praha 2, Czechia; e-mail michal.jenicek@natur.cuni.cz.

Initial submission, 1 October 2013; final acceptance 2 May 2014.

\section{Please cite this article as:}

KUČEROVÁ, D., JENÍČEK, M. (2014): Comparison of selected methods used for the calculation of the snowpack spatial distribution, Bystřice River basin, Czechia. Geografie, 119, No. 3, pp. 199-217. 